\title{
The real-life impact of vaccination on COVID-19 mortality in Europe and Israel
}

Katarzyna Jabłońska ${ }^{1}$, Samuel Aballéa ${ }^{2}$, Mondher Toumi $^{3}$

${ }^{1}$ MSc, Creativ-Ceutical, ul. Przemysłowa 12, 30-701 Kraków, Poland, katarzyna.jablonska@creativ-ceutical.com

${ }^{2}$ PhD, Creativ-Ceutical, Westblaak 90, 3012KM Rotterdam, Netherlands, samuel.aballea@creativ-ceutical.com

${ }^{3}$ Prof., Faculty of Medicine, Public Health Department, Aix-Marseille University, 27 Boulevard Jean Moulin, Marseille 13005, France, mondher.toumi@univ-amu.fr

\section{Corresponding author:}

Katarzyna Jabłońska

Creativ-Ceutical, Ul. Przemysłowa 12, 30-701 Kraków, Poland

Phone: +3317 6704790

E-mail: katarzyna.jablonska@ creativ-ceutical.com

\section{Declaration of interests:}

Funding: This research did not receive any specific grant from funding agencies in the public, commercial, or notfor-profit sectors.

Competing interests: None.

Acknowledgements: None.

Ethical approval: Not required. This study does not require ethical approval as it was conducted on country-level data and involved information freely available in the public domain.

\section{Contributors:}

MT conceptualized the study, KJ and SA validated the study concept, KJ and SA collected and analysed the data, $\mathrm{KJ}$, SA and MT interpreted the results, KJ wrote the first draft of the manuscript, KJ, SA and MT revised the manuscript and approved the final version. 


\title{
The real-life impact of vaccination on COVID-19 mortality in Europe and Israel
}

\begin{abstract}
OBJECTIVES: This study aimed at estimating the real-life impact of vaccination on COVID-19 mortality, with adjustment for SARS-CoV-2 variants spread and other factors across Europe and Israel.

METHODS: Time series analysis of daily number of COVID-19 deaths was performed using non-linear Poisson mixed regression models. Variants' frequency, demographic, climate, health and mobility characteristics of thirtytwo countries were considered as potentially relevant adjustment factors between January 2020 and April 2021.

RESULTS: The analysis revealed that vaccination efficacy in terms of protection against deaths was equal to $72 \%$, with a lower reduction of number of deaths for B.1.1.7 versus non-B.1.1.7 variants (70\% and 78\%, respectively). Other factors significantly related to mortality were arrivals at airports, mobility change from the pre-pandemic level and temperature.

CONCLUSIONS: Our study confirms a strong effectiveness of COVID-19 vaccination based on real-life public data, although lower than expected from clinical trials. This suggests the absence of indirect protection for nonvaccinated individuals. Results also show that vaccination effectiveness against mortality associated with the B.1.1.7 variant is slightly lower compared with other variants. Lastly, this analysis confirms the role of mobility reduction, within and between countries, as an effective way to reduce COVID-19 mortality and suggests the possibility of seasonal variations in COVID-19 incidence.
\end{abstract}

Keywords: COVID-19 mortality, SARS-CoV-2 variants, B.1.1.7 variant, VOC, vaccination, mobility.

\section{Introduction}

The pandemic of the coronavirus infectious disease 2019 (COVID-19) is continuously evolving, driven by the spread of new variants of severe acute respiratory syndrome coronavirus 2 (SARS-CoV-2). During the second half of 2020 and early 2021 variety of new SARS-CoV-2 variants emerged. EU2 variant (mutation S:447N) firstly observed in July 2020 in western Europe, was found to be capable of increasing virus infectivity. ${ }^{1,2}$ Then, several variants of concern (VOC) have been identified, including B.1.1.7 developed firstly in the UK in September 2020, ${ }^{3}$ B.1.351 in South Africa in December 2020, ${ }^{4}$ P.1 in Brazil in January $2021,{ }^{5}$ and the 'Indian' variant B.1.617 reported firstly in Maharashtra in January 2021. ${ }^{6}$ The disease mortality has been increased in these countries after new variants were developed. ${ }^{7-10}$ An increased risk of transmissibility, hospitalization and death associated with the B.1.1.7 variant was reported by number of authors. ${ }^{8,11-16}$ The B.1.351 variant was found to have an increased transmissibility and immune escape,${ }^{17}$ and was estimated to be $50 \%$ more transmissible than preexisting variants. ${ }^{18}$ Higher incidence of COVID-19 cases in younger age groups were observed in the Amazonas state, suggesting changes in pathogenicity of the P.1 variant. ${ }^{19}$ Preliminary findings suggest also a significant increase in case fatality rate in young and middle-aged for the P.1 mutant. ${ }^{20}$ The region of Maharashtra, where the B.1.617 variant emerged, experienced significant rise in daily infection rate after the new variant appeared. ${ }^{10}$

To control the SARS-CoV-2 spread, numbers of different vaccines have been developed and analyzed in clinical trials, including eight vaccines having emergency use or conditional marketing authorizations worldwide or across regions, as of May 2021. ${ }^{21}$ The worldwide vaccination campaign has started in December 2020 aiming to provide herd immunity across societies. The threshold for COVID-19 "herd immunity" was placed between 60-70\% of the population gaining immunity through vaccinations or past disease exposure, however, scientists warn that herd- 
immunity is unlikely to be achieved due to factors such as vaccine hesitancy and the spread of new variants. ${ }^{22,23}$ Israel was far ahead of other countries in terms of the proportion of vaccinated inhabitants, exceeding $62 \%$ at the end of April 2021, with the UK reaching 50\% and the USA $42 \%$ at the same time. ${ }^{24}$

Results of clinical trials on vaccine efficacy revealed that Pfizer-BioNTech had 95\% efficacy at preventing symptomatic COVID-19 infection in people without prior infection. ${ }^{25} 94.1 \%$ efficacy was reported for Moderna ${ }^{26}$ $70.4 \%$ for Oxford-AstraZeneca, ${ }^{27} 66.5 \%$ for Johnson \& Johnson $^{28}$ and $96.4 \%$ for Novavax, ${ }^{29}$ with the latter being still under the investigation before authorization. For the prevention against a severe disease course, Pfizer, Moderna, AstraZeneca and Novavax reported a $100 \%$ efficacy, whereas $84 \%$ was observed for Johnson \& Johnson, however, the latter was tested on a broader range of countries, including the USA, South Africa and Brazil, after the new VOCs spread.

Clinical evidence suggests that newly developed virus variants may affect the protective efficacy of both naturally acquired immunity and of vaccinations. Studies on neutralization of convalescent sera against distinct strains showed that VOCs were harder to neutralize than the original strain, an early Wuhan-related strain of SARS-CoV-2. Neutralization titers against the B.1.1.7 variant showed a 3-fold reduction, ${ }^{30}$ a 3.4-fold reduction was observed for the P.1 variant, ${ }^{31}$ and a 13.3 -fold reduction for the B.1.531 variant. ${ }^{32}$ Johnson \& Johnson vaccine was found to have 64\% efficacy against infection in South Africa and 68\% in Brazil after the spread of B.1.135 and P.1 variants, whereas the efficacy against severe-critical disease was $82 \%$ and $88 \%$ in both countries, respectively. ${ }^{28}$ Late March 2021, AstraZeneca was observed as having $70.4 \%$ efficacy against the B.1.1.7 variant, ${ }^{33}$ however, the vaccine did not protect as well against B.1.351 variant. ${ }^{34}$ For Novavax, the initial evidence suggests $86.3 \%$ efficacy against B.1.1.7 variant ${ }^{35}$ and $49.4 \%$ against B.1.351. ${ }^{36}$ Early May 2021, Pfizer vaccine was found to be $87 \%$ effective against infection with B.1.1.7 variant and $72 \%$ against B.1.351 variant, whereas $97.4 \%$ efficacy against severe disease course was observed for any of these mutations. ${ }^{37}$ On the other hand, Wang (et al.) observed a reduced neutralization of Moderna and Pfizer vaccine-immune sera against B.1.351 variant (12.4-fold for Moderna; 10.3fold for Pfizer), but no significant impact was observed for B.1.1.7 variant. ${ }^{38}$ Next, a 3.8-4.8-fold reduced neutralization of Moderna vaccine was observed against P.1 variant. ${ }^{31}$ Preliminary evidence suggests a significant drop in neutralization of B.1.617 compared to other variants, including B.1.1.7 and P.1, with sera of Indian's vaccine, Covaxine. ${ }^{10}$

The other concern is the probability of re-infection after recovery or vaccination. Hansen (et al.) observed an $80.5 \%$ protection against re-infection in a population-level observational study on Danish patients previously tested positive for SARS-CoV-2, ${ }^{39}$ however, the study was performed before VOCs spread. The probability of re-infection after vaccination is also a big concern. As reported by the USA Centers for Disease Control and Prevention (CDC), there were around 9200 infections among vaccinated inhabitants among 95 million of those who have already been vaccinated in the USA $(0.01 \%)$ as of 26 April $2021 .^{40}$ Despite this optimistic preliminary data, effects of vaccination were not reliably assessed in a longer perspective thus far. The real-world evidence on vaccination effectiveness is still sparse. Experts alarm that additional data are needed to assess the potential impact of VOCs on future vaccine efficacy. ${ }^{41}$ Considering all the concerns associated with new VOCs spread, the real vaccination effectiveness becomes hard to assess and prognose but can be expected to decrease over time. Also, it is likely that vaccination may favour the emergence of new variants by selection of new, better fitted mutants. Some scientists suggest that, similarly as for seasonal flu vaccines, COVID-19 vaccines will need to be redesigned or even updated periodically to protect against new variants. ${ }^{42,43}$

Vaccination efficacy and distinct variants spread are only two factors among numerous other variables affecting COVID-19 infection and death rates across the world. A variety of potential predictors were assessed in the literature, including demographic characteristics, mobility and social-distancing measures, environmental and climate variables, as well as health characteristics. ${ }^{4-53}$

This study aims at estimating the real-life impact of vaccination on COVID-19 mortality based on publicly available data from Europe and Israel, using time series analysis with non-linear mixed regression models. Variants 
medRxiv preprint doi: https://doi.org/10.1101/2021.05.26.21257844; this version posted May 29, 2021. The copyright holder for this preprint (which was not certified by peer review) is the author/funder, who has granted medRxiv a license to display the preprint in perpetuity. All rights reserved. No reuse allowed without permission.

frequency, including B.1.1.7 and other variants, as well as country-specific demographic and meteorological characteristics, health indicators and mobility factors were considered as potentially relevant adjustment factors. Results of the current study should inform policy decision makers, scientists, and the general public about the role of vaccination and social-distancing strategies in controlling the COVID-19 pandemic in the face of new VOCs spread.

\section{Methods}

\section{Data collection}

A total of 32 countries were considered in the analysis, including European countries and Israel. The daily number of COVID-19 deaths was the primary outcome of interest. Values were smoothed using 7-day moving average, divided by the number of inhabitants of a given country and reported as daily numbers of deaths per 1 million inhabitants.

The main explanatory variables of interest were proportion of vaccinated inhabitants (vaccination coverage), as well as average proportions of SARS-CoV-2 variants calculated across strains forming twelve Nextstrain clades. The focus was on 20A (EU2), 20E (EU1) and 20I (B.1.1.7) variants, with two formers being dominant in Europe during the summer 2020, and the latter VOC being most frequent early 2021. Other time-varying covariates considered in the analysis were maximum daily temperature, mean daily wind speed, number of arrivals at two biggest airports of a country and change in mobility from pre-pandemic level (considering the average across retail/recreation, transit stations and groceries/pharmacies). Additional fixed covariates were proportion of population aged 65 or more, prevalence of diabetes and rate of cardiovascular deaths.

Data on COVID-19 deaths and vaccination were obtained from Our World In Data on 15 April $2021 .{ }^{24}$ Meta-data on SARS-CoV-2 virus variants (clades) identified up to mid-April 2021 was downloaded from the Nextstrain platform. ${ }^{54-56}$ We assumed that if a strain was observed on a given date, it could be observed in a range of \pm 14 days from the observation date. Since the data were not reported daily, linear interpolation was used to impute missing observations, assuming zeros a month before the first and after the last (if up to 1 March 2021) reported occurrence of a variant. Finally, data were smoothed with the use of 14-day moving average.

Countries' characteristics were obtained from Our World In Data, Eurostat, National Centers for Environmental Information, Aviation Intelligence Portal and Google COVID-19 Community Mobility Reports. ${ }^{24,57-60}$ Data on arrival flights and mobility were smoothed using 7-day moving average.

\section{Statistical analysis}

Regression analysis was used to investigate the association between COVID-19 mortality and daily reported timevarying variables and fixed covariates.

The primary analysis of daily number of COVID-19 deaths was performed with the use of non-linear Poisson mixed model with random country-level intercept and mobility effects. The considered period was from the date of first reported death in Europe, 29 January 2020, up to 15 April 2021.

Due to the presence of autocorrelations, and to consider the fact that the number of infections on a given day is dependent on the number of infectious cases in the population over previous days, the model was adjusted for the logarithm of daily number of COVID-19 deaths reported 7 days earlier. To capture the fact that increasing or decreasing trends in COVID-19 mortality over time are generally stable over several weeks or months, the logarithm of quotient of COVID-19 deaths 7 days before divided by deaths 14 days before the actual date was added as a covariate. All other time-varying variables were considered with a 21-day lag, to account for the virus incubation period and the delay between being infected and die due to the disease. In addition, heterogeneity between countries was considered with random intercepts and mobility effects varying between countries. 
Assuming $M$ indicates mortality with a vaccination coverage ' $c$ ', $M_{O}$ is the mortality without vaccination and ' $V E$ ' represents the vaccine efficacy, we have:

$$
M=M_{0} \cdot(1-c \cdot V E)
$$

After applying the logarithmic transformation and considering a set of covariates $x_{1}, \ldots, x_{k}$ and random effects $u_{0}, u_{1}, \ldots, u_{n}$ on intercept and selected $x_{1}, \ldots, x_{n}$, the equation above was extended as shown below to specify the non-linear model:

$$
\log (E(M))=\beta_{0}+\log ((1-c \cdot V E))+\beta_{1} x_{1}+\cdots+\beta_{k} x_{k}+u_{0}+u_{1} x_{1}+\cdots+u_{n} x_{n} .
$$

For the exploratory analysis, vaccine efficacy against B.1.1.7 and non-B.1.1.7 variants was analyzed using a similar approach. Assuming that there are two classes of virus variants with known proportions equaled $p_{1}$ and $p_{2}$, the vaccine efficacy could be considered as the average efficacy weighted by variants proportions:

$$
V E=p_{1} \cdot V E_{1}+p_{2} \cdot V E_{2} .
$$

The formula for the non-linear model is then as follows:

$$
\log (E(M))=\beta_{0}+\log \left(\left(1-c \cdot\left(p_{1} \cdot V E_{1}+p_{2} \cdot V E_{2}\right)\right)\right)+\beta_{1} x_{1}+\cdots+\beta_{k} x_{k}+u_{0}+u_{1} x_{1}+\cdots+u_{n} x_{n} .
$$

A p-value lower than 0.05 was considered as statistically significant. Akaike's Information Criterion (AIC) was provided to inform about models' fit statistic. Analyses were performed using SAS 9.4 software.

\section{Results}

\section{Descriptive statistics}

Descriptive statistics of outcomes and covariates across 32 countries included in the analysis, for the period between January 2020 and April 2021 are presented in Table 1. Cumulative numbers of COVID-19 deaths per inhabitant across countries during this period are presented in Figure 1. The highest numbers were observed for central and south-east countries: Czechia, Hungary, Bosnia and Herzegovina. Mean proportions of SARS-CoV-2 variants, EU2, EU1 and B.1.1.7 for each country are presented in Figure 2. Up to mid-April 2021, the variant EU2 was the most frequently spread for vast majority of countries, except Israel and the UK for which B.1.1.7 was more frequent, as well as Spain and Lithuania with EU1 being more commonly observed.

\section{Primary analysis}

Analysis of the non-linear Poisson mixed model of number of COVID-19 deaths revealed that the effect of vaccination efficacy against mortality was assessed as significant and equalled to $0.720(\mathrm{p}<0.001$; Table 2). Other covariates which were found significant in the model were: temperature $(-0.005, \mathrm{p}<0.001)$, arrivals at airports $(0.709, \mathrm{p}<0.001)$ and mobility change from pre-pandemic level $(0.753, \mathrm{p}<0.001)$. Variables used to account for autocorrelation and minimize the effect of trend were assessed as significant (Log of number of daily COVID-19 deaths: 0.926, $\mathrm{p}<0.001$; Log of number of COVID-19 deaths 7 days before / 14 days before: $0.158, \mathrm{p}<0.010$ ).

\section{Exploratory analysis}

Results of the analysis of the exploratory model revealed numerically lower vaccine efficacy against B.1.1.7 than against non-B.1.1.7 variants, although the difference was not statistically significant $(0.697, \mathrm{p}=0.002$ and 0.778 , $\mathrm{p}=0.049$, respectively; Table 3). The same set of covariates were found significant in the exploratory model as in the primary analysis: temperature $(-0.005, \mathrm{p}<0.001)$, arrivals at airports $(0.703, \mathrm{p}<0.001)$ and mobility change from prepandemic level $(0.753, \mathrm{p}<0.001)$. Variables used to account for autocorrelation and minimize the effect of trend were assessed as significant (Log of number of daily COVID-19 deaths: 0.926, p<0.001; Log of number of COVID19 deaths 7 days before / 14 days before: $0.158, \mathrm{p}<0.010$ ). 


\section{Discussion}

In this study we investigated the association between daily mortality due to COVID-19 and vaccination coverage, proportions of SARS-CoV-2 variants and additional factors, such as demographics, health, mobility and meteorological variables, analyzing country-level data across Europe and Israel. Results of the analysis suggest that vaccination effectiveness against deaths is equal to $72 \%$, and that it is slightly lower against the B.1.1.7 variant compared to non-B.1.1.7 variants (difference not statistically significant). These findings suggest lower effectiveness against death than reported efficacy against severe or critical disease course in clinical trials of vaccines $(84-100 \%){ }^{25-29}$

This lower than expected effectiveness might be explained by the difference in considered populations: clinical trials included restrictive populations and our study covers general populations, irrespective of age, concomitant therapies, medical condition and general condition. In particular, vaccinated people in real life are older on average than subjects enrolled in clinical trials (12.2\% aged $\geq 55$ in AstraZeneca trial; 24.7\% aged $\geq 65$ in Moderna trial; 33.5\% aged $\geq 60$ in Johnson \& Johnson trial; $42.3 \%$ aged $\geq 55$ in Pfizer trial). However, our results suggesting lower protection against B.1.1.7 variant, are consistent with reported data so far from in vivo experiments and patient level studies, providing an external validation of these findings. Laboratory evidence revealed a slight reduction in neutralization against B.1.1.7 variant compared to the original strain. Neutralization titers against this VOC were 3fold lower when analyzing convalescent sera, and 3.3-fold and 2.5-fold lower for Pfizer and AstraZeneca vaccinees, respectively. ${ }^{30}$ Real-world studies on B.1.1.7 VOC suggested that it caused increased mortality compared to nonB.1.1.7 variants, ${ }^{15,61}$ which, therefore, might not have been contained with similar effectiveness by vaccination. Our results evoke the question of variants evading vaccine antibodies in the future and the need to adapt such vaccine for each new season, which was earlier suggested by experts. ${ }^{42,43}$

While the utilization of individual-level data, collected in real-world setting, could provide more precise estimates of vaccine effectiveness, the use of aggregate data at country level also has a major advantage: the vaccination impact estimated in this analysis should capture the indirect protection provided by vaccination. If the vaccine protects against infection, the number of infectious cases would decrease as more people are vaccinated. The lower number of infectious cases in the population would lead to a reduced probability for susceptible individuals to get in contact with infectious cases, thus leading to a reduction in incidence among all people, including non-vaccinated people. This indirect protection can be captured when comparing different populations with different rates of vaccination coverage, but could not be captured when comparing vaccinated and non-vaccinated individuals from the same population. Interestingly, the fact that our estimated vaccine effectiveness is relatively low compared to vaccine efficacy reported in clinical trials suggests that there is no or little indirect protection provided by vaccination. This could indicate that the vaccine protects against disease but not against infection, or that vaccinated groups of population are not those that contribute to the propagation of the virus.

A positive relationship between number of arrivals at airports and mortality has been observed in this analysis, similarly as between mobility change and mortality. It suggests that both increased long-distance travel and increased mobility are strong predictors of growth in daily number of COVID-19 deaths. These findings highlight the role of mobility reduction, both within and between countries, as an effective way to reduce COVID-19 mortality, especially when new virus variants emerge and spread across the world. Our results are in line with previous study by Jabłońska (et al.) suggesting that countries with lower reduction in mobility at the beginning of the pandemic experienced a higher COVID-19 daily deaths peak. ${ }^{50}$ The role of social distancing was also underlined by Badr (et al.) who observed a significant impact of mobility on COVID-19 transmission in the USA. ${ }^{62}$

The daily temperature was found as a significant predictor of COVID-19 mortality in this study, with increasing temperature associated with the reduction in number of deaths. Kerr (et al.) found no consensus on the impact of meteorological factors on COVID-19 spread in their literature review, however, they suggested existence of environmental sensitivity of COVID-19, but not as significant as non-pharmaceutical interventions and human 
behavior. ${ }^{63}$ Several authors underlined that disease seasonality may exist, ${ }^{64-67}$ including Liu (et al.) who found that COVID-19 infection and mortality rates were higher in colder climates and that the cold season caused an increase in total infections, while the warm season contributed to the opposite effect. ${ }^{66}$ Since our analysis covered a full annual cycle of COVID-19, our result suggests the possibility of seasonal variations in COVID-19 incidence. Such seasonality has been well established in temperate climate for other respiratory viruses. ${ }^{68,69}$

\section{Limitations}

Our study has several limitations. Firstly, our analysis was conducted on a country-level basis to estimate the vaccination efficacy, which should be seen as less precise method compared to analysis of individual-level data, as previously noted. However, given the range of included countries, our results shed light on the problem of vaccination effectiveness from a broader perspective and investigate the effect of vaccination across societies, considering variability of vaccination coverage through time and between countries. Secondly, the quality of data on variants distribution varied between countries and was low for some of them, therefore, results of the exploratory analysis should be treated with cautious. To limit bias and avoid fluctuations, we employed methods of interpolation and smoothing. Countries with limited data were excluded. Thirdly, the set of covariates used in the multivariate analysis can be assessed as non-exhaustive. We decided to consider factors which were previously assessed as significantly impacting the risk of severe illness or mortality from COVID-19 in the literature ${ }^{50-53}$ Finally, we were not able to consider other new SARS-CoV-2 VOCs, except B.1.1.7, in the current analysis, which was due to their limited spread in Europe as of April 2021. It rises a need for further research on this topic in the future.

\section{Conclusions}

This study confirms a strong effectiveness of COVID-19 vaccination based on real-life public data, in terms of protection against deaths being around $72 \%$, although it appears to be slightly lower than could be expected from clinical trial results. This suggests the absence of indirect protection for non-vaccinated individuals. Results also suggests that vaccination effectiveness against mortality associated with the B.1.1.7 variant is high but slightly lower compared with other variants ( $70 \%$ and $78 \%$, respectively). Finally, this analysis confirms the role of mobility reduction, both within and between countries, as an effective way to reduce COVID-19 mortality and supports the possibility of seasonal variations in COVID-19 incidence.

\section{References}

1. Liu Z, VanBlargan LA, Rothlauf PW, et al. Landscape analysis of escape variants identifies SARS-CoV-2 spike mutations that attenuate monoclonal and serum antibody neutralization. bioRxiv 2020: 2020.11.06.372037.

2. Hodcroft EB. CoVariants: SARS-CoV-2 Mutations and Variants of Interest. 2021. https://covariants.org/ (accessed 15th March 2021).

3. Rambaut A, Loman N, Pybus O. Preliminary Genomic Characterisation of an Emergent SARS-CoV-2 Lineage in the UK Defined by a Novel Set of Spike Mutations. https://virological.org/t/preliminary-genomiccharacterisation-of-an-emergent-sars-cov-2-lineage-in-the-uk-defined-by-a-novel-set-of-spike-mutations/563 (accessed 15th March 2021).

4. Tegally H, Wilkinson E, Giovanetti M, et al. Emergence and rapid spread of a new severe acute respiratory syndrome-related coronavirus 2 (SARS-CoV-2) lineage with multiple spike mutations in South Africa. medRxiv 2020: 2020.12.21.20248640.

5. Faria N, Claro I, Candido D, et al. Genomic characterisation of an emergent SARS-CoV-2 lineage in Manaus: preliminary findings. 2021. https://virological.org/t/genomic-characterisation-of-an-emergent-sars-cov-2lineage-in-manaus-preliminary-findings/586 (accessed 21 April 2021).

6. Barnagarwala T, Mascarenhas A. Explained: B.1.617 variant and the Covid-19 surge in India. 2021. https://indianexpress.com/article/explained/maharashtra-double-mutant-found-b-1-617-variant-and-the-surge7274080/ (accessed 27 April 2021). 
medRxiv preprint doi: https://doi.org/10.1101/2021.05.26.21257844; this version posted May 29, 2021. The copyright holder for this preprint (which was not certified by peer review) is the author/funder, who has granted medRxiv a license to display the preprint in perpetuity.

All rights reserved. No reuse allowed without permission.

7. Naveca F, da Costa C, Nascimento V. SARS-CoV-2 reinfection by the new Variant of Concern (VOC) P.1 in Amazonas, Brazil. 2021. https://virological.org/t/sars-cov-2-reinfection-by-the-new-variant-of-concern-voc-p-1in-amazonas-brazil/596 (accessed 16th March 2021).

8. Iacobucci G. Covid-19: New UK variant may be linked to increased death rate, early data indicate. $B M J$ 2021; 372: n230.

9. Jassat W, Mudara C, Ozougwu L, et al. Increased mortality among individuals hospitalised with COVID19 during the second wave in South Africa. medRxiv 2021: 2021.03.09.21253184.

10. Yadav PD, Sapkal GN, Abraham P, et al. Neutralization of variant under investigation B.1.617 with sera of BBV152 vaccinees. bioRxiv 2021: 2021.04.23.441101.

11. Wallace DJ, Ackland GJ. Abrupt increase in the UK coronavirus death-case ratio in December 2020. medRxiv 2021: 2021.01.21.21250264.

12. Challen R, Brooks-Pollock E, Read JM, Dyson L, Tsaneva-Atanasova K, Danon L. Risk of mortality in patients infected with SARS-CoV-2 variant of concern 202012/1: matched cohort study. BMJ 2021; 372: n579.

13. New and Emerging Respiratory Virus Threats Advisory Group (NERVTAG). Resport to SAGE: Increased disease severity in people infected with variant of concern (VOC) B.1.1.7 compared to people infected with nonVOC virus variants. 2021. https://assets.publishing.service.gov.uk/government/uploads/system/uploads/attachment_data/file/961042/S1095_N ERVTAG_update_note_on_B.1.1.7_severity_20210211.pdf (accessed 15th March 2021).

14. Public Health England. SARS-CoV-2 variants of concern and variants under investigation in England. Technical briefing 7. 11th March 2021. https://www.gov.uk/government/publications/investigation-of-novel-sarscov-2-variant-variant-of-concern-20201201,

https://assets.publishing.service.gov.uk/government/uploads/system/uploads/attachment_data/file/968581/Variants_ of_Concern_VOC_Technical_Briefing_7_England.pdf (accessed 15th March 2021).

15. Davies NG, Jarvis CI, van Zandvoort K, et al. Increased mortality in community-tested cases of SARSCoV-2 lineage B.1.1.7. Nature 2021.

16. Davies NG, Abbott S, Barnard RC, et al. Estimated transmissibility and impact of SARS-CoV-2 lineage B.1.1.7 in England. Science 2021; 372(6538): eabg3055.

17. Tegally H, Wilkinson E, Giovanetti M, et al. Detection of a SARS-CoV-2 variant of concern in South Africa. Nature 2021; 592(7854): 438-43.

18. Pearson C, Russell T, Davies N, et al. Estimates of severity and transmissibility of novel SARS-CoV-2 variant 501Y.V2 in South Africa.

19. Freitas ARR, Beckedorff OA, de Góes Cavalcanti LP, Siqueira AM, et al. The emergence of novel SARSCoV-2 variant P.1 in Amazonas (Brazil) was temporally associated with a change in the age and gender profile of COVID-19 mortality. 2021.

20. de Oliveira MHS, Lippi G, Henry BM. Sudden rise in COVID-19 case fatality among young and middleaged adults in the south of Brazil after identification of the novel B.1.1.28.1 (P.1) SARS-CoV-2 strain: analysis of data from the state of Parana. medRxiv 2021: 2021.03.24.21254046.

21. The New York Times. Coronavirus Vaccine Tracker. 2021. https://www.nytimes.com/interactive/2020/science/coronavirus-vaccine-tracker.html (accessed 12 May 2021).

22. Aschwanden C. Five reasons why COVID herd immunity is probably impossible. 2021. https://www.nature.com/articles/d41586-021-00728-2 (accessed 27 April 2021).

23. Gu Y. Path to Normality: 2021 Outlook of COVID-19 in the US. 2021. https://covid19projections.com/path-to-herd-immunity/ (accessed 27 April 2021).

24. Our World In Data. Coronavirus (COVID-19) Vaccinations. 2021. https://ourworldindata.org/covidvaccinations (accessed 27 April 2021).

25. Polack FP, Thomas SJ, Kitchin N, et al. Safety and Efficacy of the BNT162b2 mRNA Covid-19 Vaccine. New England Journal of Medicine 2020; 383(27): 2603-15.

26. Baden LR, El Sahly HM, Essink B, et al. Efficacy and Safety of the mRNA-1273 SARS-CoV-2 Vaccine. The New England journal of medicine 2021; 384(5): 403-16. 
medRxiv preprint doi: https://doi.org/10.1101/2021.05.26.21257844; this version posted May 29, 2021. The copyright holder for this preprint (which was not certified by peer review) is the author/funder, who has granted medRxiv a license to display the preprint in perpetuity.

All rights reserved. No reuse allowed without permission.

27. Voysey M, Clemens SAC, Madhi SA, et al. Safety and efficacy of the ChAdOx1 nCoV-19 vaccine (AZD1222) against SARS-CoV-2: an interim analysis of four randomised controlled trials in Brazil, South Africa, and the UK. The Lancet 2021; 397(10269): 99-111.

28. Sadoff J, Gray G, Vandebosch A, et al. Safety and Efficacy of Single-Dose Ad26.COV2.S Vaccine against Covid-19. New England Journal of Medicine 2021.

29. Novavax Inc. Novavax Confirms High Levels of Efficacy Against Original and Variant COVID-19 Strains in United Kingdom and South Africa Trials. 11 March 2021 2021. https://ir.novavax.com/news-releases/newsrelease-details/novavax-confirms-high-levels-efficacy-against-original-and-0.

30. Supasa P, Zhou D, Dejnirattisai W, et al. Reduced neutralization of SARS-CoV-2 B.1.1.7 variant by convalescent and vaccine sera. Cell 2021; 184(8): 2201-11.e7.

31. Wang P, Casner RG, Nair MS, et al. Increased Resistance of SARS-CoV-2 Variant P.1 to Antibody Neutralization. bioRxiv 2021: 2021.03.01.433466.

32. Zhou D, Dejnirattisai W, Supasa P, et al. Evidence of escape of SARS-CoV-2 variant B.1.351 from natural and vaccine-induced sera. Cell 2021.

33. Emary KRW, Golubchik T, Aley PK, et al. Efficacy of ChAdOx1 nCoV-19 (AZD1222) vaccine against SARS-CoV-2 variant of concern 202012/01 (B.1.1.7): an exploratory analysis of a randomised controlled trial. The Lancet 2021; 397(10282): 1351-62.

34. University of Oxford. ChAdOx1 nCov-19 provides minimal protection against mild-moderate COVID-19 infection from B.1.351 coronavirus variant in young South African adults. 2021. https://www.research.ox.ac.uk/Article/2021-02-07-chadox1-ncov-19-minimal-protection-against-mild-covid-19from-b-1-351-variant-in-young-sa-adults (accessed 27 April 2021).

35. Heath PT, Galiza EP, Baxter DN, et al. Efficacy of the NVX-CoV2373 Covid-19 Vaccine Against the B.1.1.7 Variant. medRxiv 2021: 2021.05.13.21256639.

36. Shinde V, Bhikha S, Hoosain Z, et al. Efficacy of NVX-CoV2373 Covid-19 Vaccine against the B.1.351 Variant. New England Journal of Medicine 2021.

37. Abu-Raddad LJ, Chemaitelly H, Butt AA. Effectiveness of the BNT162b2 Covid-19 Vaccine against the B.1.1.7 and B.1.351 Variants. New England Journal of Medicine 2021.

38. Wang P, Nair MS, Liu L, et al. Antibody resistance of SARS-CoV-2 variants B.1.351 and B.1.1.7. Nature 2021; 593(7857): 130-5.

39. Hansen CH, Michlmayr D, Gubbels SM, Mølbak K, Ethelberg S. Assessment of protection against reinfection with SARS-CoV-2 among 4 million PCR-tested individuals in Denmark in 2020: a population-level observational study. The Lancet 2021; 397(10280): 1204-12.

40. Centers for Disease Control and Prevention. COVID-19 Breakthrough Case Investigations and Reporting. 2021. https://www.cdc.gov/vaccines/covid-19/health-departments/breakthrough-cases.html (accessed 11 May 2021).

41. Sanders RW, de Jong MD. Pandemic moves and countermoves: vaccines and viral variants. The Lancet 2021; 397(10282): 1326-7.

42. Callaway E, Ledford H. How to redesign COVID vaccines so they protect against variants. Nature 2021; 590(7844): $15-6$.

43. Bian L, Gao F, Zhang J, et al. Effects of SARS-CoV-2 variants on vaccine efficacy and response strategies. Expert Review of Vaccines 2021: 1-9.

44. Aldibasi OS, Alharbi NK, Alkelya M, Zowawi H, Alghnam S. The Association of Country-Level Factors with Outcomes of COVID-19: Analysis of the pandemic after one million cases. Research Square 2020.

45. Burden SJ, Rademaker J, Weedon BD, Whaymand L, Dawes H, Jones A. Associations of Global Country Profiles and Modifiable Risk Factors with COVID-19 Cases and Deaths. medRxiv 2020: 2020.06.17.20133454.

46. Sorci G, Faivre B, Morand S. Why Does COVID-19 Case Fatality Rate Vary Among Countries? The Lancet 2020.

47. Garcia de Alcaniz JG, Romero-Lopez J, Martinez RP, Lopez-Rodas V, Costas E. What variables can better predict the number of infections and deaths worldwide by SARS-CoV-2? Variation through time. medRxiv 2020: 2020.06.04.20122176. 
medRxiv preprint doi: https://doi.org/10.1101/2021.05.26.21257844; this version posted May 29, 2021. The copyright holder for this preprint (which was not certified by peer review) is the author/funder, who has granted medRxiv a license to display the preprint in perpetuity.

All rights reserved. No reuse allowed without permission.

48. Woody S, Garcia Tec M, Dahan M, et al. Projections for first-wave COVID-19 deaths across the US using social-distancing measures derived from mobile phones. medRxiv 2020: 2020.04.16.20068163.

49. Courtemanche C, Garuccio J, Le A, Pinkston J, Yelowitz A. Strong Social Distancing Measures In The United States Reduced The COVID-19 Growth Rate. Health Affairs; 0(0): 10.1377/hlthaff.2020.00608.

50. Jabłońska K, Aballéa S, Toumi M. Factors influencing the COVID-19 daily deaths' peak across European countries. Public Health 2021; 194: 135-42.

51. Sanyaolu A, Okorie C, Marinkovic A, et al. Comorbidity and its Impact on Patients with COVID-19. SN Compr Clin Med 2020: 1-8.

52. Centers for Disease Control and Prevention. COVID-19: People at increased risk with certain medical conditions. 2021. https://www.cdc.gov/coronavirus/2019-ncov/need-extra-precautions/people-with-medicalconditions.html (accessed 15th March 2021).

53. Omar SA, Naif KA, Mohamed A, Hosam Z, Suliman A. The Association of Country-Level Factors with Outcomes of COVID-19: Analysis of the pandemic after one million cases. Research Square 2021.

54. Hadfield et al. Nextstrain: real-time tracking of pathogen evolution Bioinformatics 2018.

55. Bedford T, Neher R, Hadfield J, et al. Nextstrain - Real-time tracking of pathogen evolution. 2021. https://nextstrain.org/ (accessed 15th March 2021).

56. Global Initiative on Sharing All Influenza Data (GISAID). The GISAID Initiative. https://www.gisaid.org/ (accessed 14th March 2021).

57. Eurostat. Eurostat Database. 2021. https://ec.europa.eu/eurostat/data/database (accessed 29 April 2021 2021).

58. National Centers for Environmental Information. Global Surface Summary of the Day. 2021. https://www.ncei.noaa.gov/access/search/data-search/global-summary-of-the-day (accessed 15 April 2021).

59. EUROCONTROL. Aviation Intelligence Portal. 2021. https://ansperformance.eu/data/ (accessed 15 April $20212021)$.

60. Google. COVID-19 Community Mobility Reports. 2021. https://www.google.com/covid19/mobility/ (accessed 15 April 2021 2021).

61. Jabłońska K, Aballéa S, Auquier P, Toumi M. On the association between SARS-COV-2 variants and COVID-19 mortality during the second wave of the pandemic in Europe. medRxiv 2021: 2021.03.25.21254289.

62. Badr HS, Du H, Marshall M, Dong E, Squire MM, Gardner LM. Association between mobility patterns and COVID-19 transmission in the USA: a mathematical modelling study. The Lancet Infectious Diseases 2020; 20(11): 1247-54.

63. Kerr GH, Badr HS, Gardner LM, Perez-Saez J, Zaitchik BF. Associations between meteorology and COVID-19 in early studies: Inconsistencies, uncertainties, and recommendations. One Health 2021; 12: 100225.

64. Merow C, Urban MC. Seasonality and uncertainty in global COVID-19 growth rates. Proceedings of the National Academy of Sciences 2020; 117(44): 27456-64.

65. Engelbrecht FA, Scholes RJ. Test for Covid-19 seasonality and the risk of second waves. One Health 2021; 12: 100202 .

66. Liu X, Huang J, Li C, et al. The role of seasonality in the spread of COVID-19 pandemic. Environ Res 2021; 195: 110874-.

67. Audi A, AlIbrahim M, Kaddoura M, Hijazi G, Yassine HM, Zaraket H. Seasonality of Respiratory Viral Infections: Will COVID-19 Follow Suit? Frontiers in Public Health 2020; 8(576).

68. Moriyama M, Hugentobler WJ, Iwasaki A. Seasonality of Respiratory Viral Infections. Annual Review of Virology 2020; 7(1): 83-101.

69. Martinez ME. The calendar of epidemics: Seasonal cycles of infectious diseases. PLOS Pathogens 2018; 14(11): e1007327. 
medRxiv preprint doi: https://doi.org/10.1101/2021.05.26.21257844; this version posted May 29, 2021. The copyright holder for this preprint (which was not certified by peer review) is the author/funder, who has granted medRxiv a license to display the preprint in perpetuity. All rights reserved. No reuse allowed without permission.

Tables

Table 1. Descriptive statistics of outcomes and covariates across 32 countries (January 2020 - April 2021)

\begin{tabular}{|l|r|r|r|r|r|r|r|r|}
\hline Variable & \multicolumn{1}{|c|}{$\mathbf{N}$} & \multicolumn{1}{|c|}{ Mean } & $\begin{array}{l}\text { Standard } \\
\text { Deviation }\end{array}$ & Median & $\begin{array}{c}\text { Lower } \\
\text { Quartile }\end{array}$ & \multicolumn{1}{c|}{$\begin{array}{c}\text { Upper } \\
\text { Quartile }\end{array}$} & Minimum & Maximum \\
\hline Number of daily COVID-19 deaths & 13229 & 3.355 & 4.618 & 1.159 & 0.206 & 4.933 & 0 & 28.770 \\
\hline Proportion of vaccinated inhabitants & 13181 & 0.018 & 0.058 & 0 & 0 & 0 & 0 & 0.616 \\
\hline Proportion of 20A (EU2) variant & 13106 & 0.349 & 0.250 & 0.313 & 0.154 & 0.509 & 0 & 1.000 \\
\hline Proportion of 20E (EU1) variant & 12754 & 0.090 & 0.159 & 0 & 0 & 0.114 & 0 & 0.741 \\
\hline Proportion of 20I (B.1.1.7) variant & 13099 & 0.124 & 0.256 & 0 & 0 & 0.065 & 0 & 1.000 \\
\hline Max daily temperature & 13008 & 15.597 & 9.347 & 15.833 & 8.750 & 22.389 & -17.111 & 43.111 \\
\hline Mean daily wind speed & 13010 & 6.227 & 3.353 & 5.600 & 3.700 & 8.100 & 0.100 & 25.800 \\
\hline Arrivals at two biggest airports & 12748 & 140.609 & 195.648 & 66.429 & 27.714 & 177.929 & 1.857 & 1780.143 \\
\hline Mobility change from pre-pandemic ${ }^{1}$ & 12918 & -0.217 & 0.170 & -0.201 & -0.322 & -0.091 & -0.792 & 0.199 \\
\hline Proportion of inhabitants aged $\geq 65$ & 13229 & 0.184 & 0.025 & 0.190 & 0.168 & 0.198 & 0.117 & 0.230 \\
\hline Diabetes prevalence & 13229 & 0.062 & 0.019 & 0.058 & 0.048 & 0.072 & 0.033 & 0.101 \\
\hline Cardiovascular death rate & 13229 & 2.037 & 1.124 & 1.535 & 1.148 & 2.783 & 0.861 & 5.398 \\
\hline
\end{tabular}

1 Average mobility change from pre-pandemic calculated across retail/recreation, transit stations and groceries/pharmacies [0.01].

Descriptive statistics were calculated for 32 countries based on daily data between 29 January 2020 and 15 April 2021.

Table 2. Results of the non-linear Poisson mixed model of number of daily COVID-19 deaths

\begin{tabular}{|c|c|c|c|}
\hline Variable & Estimate & Standard Error & P value \\
\hline Intercept & 0.467 & 0.202 & 0.028 \\
\hline Logarithm of number of daily COVID-19 deaths ${ }^{\#}$ & 0.926 & 0.007 & $<0.001$ \\
\hline Logarithm of (number of COVID-19 deaths 7 days before / 14 days before) & 0.158 & 0.015 & $<0.001$ \\
\hline Proportion of 20A (EU2) variant* & 0.012 & 0.036 & 0.746 \\
\hline Proportion of 20E (EU1) variant* & -0.032 & 0.046 & 0.501 \\
\hline Proportion of 20I (B.1.1.7) variant* & 0.059 & 0.033 & 0.084 \\
\hline Max daily temperature* & -0.005 & 0.001 & $<0.001$ \\
\hline Mean daily wind speed $*$ & -0.002 & 0.002 & 0.351 \\
\hline Arrivals at two biggest airports [in thousands]* & 0.709 & 0.085 & $<0.001$ \\
\hline Mobility change from pre-pandemic ${ }^{* 1}$ & 0.753 & 0.064 & $<0.001$ \\
\hline Proportion of inhabitants aged $\geq 65^{\wedge}$ & -1.238 & 0.930 & 0.193 \\
\hline Diabetes prevalence & 0.544 & 1.293 & 0.677 \\
\hline Cardiovascular death rate $^{\wedge}$ & 0.023 & 0.023 & 0.322 \\
\hline Vaccination efficacy* & 0.720 & 0.132 & $<0.001$ \\
\hline Variance for RE on intercept & 0.014 & 0.006 & 0.023 \\
\hline Variance for RE on mobility & 0.036 & 0.023 & 0.126 \\
\hline \multicolumn{4}{|c|}{$\begin{array}{l}\text { \#Time-varying variable with a 7-days lag. } \\
\text { * Time-varying variable with a } 21 \text {-days lag. } \\
\text { } \text { Fixed variable. } \\
{ }^{1} \text { Average mobility change from pre-pandemic calculated across retail/recreation, transit stations and groceries/pharmacies [0.01]. } \\
\text { Abbreviations: AIC = Akaike's Information Criterion; } \mathrm{mln}=\text { million; } \mathrm{RE}=\mathrm{random} \text { effects. } \\
\text { Non-linear Poisson mixed model of daily number of COVID-19 deaths per } 1 \mathrm{mln} \text { inhabitants, with country-specific random effects on intercept } \\
\text { and mobility. Daily data for } 32 \text { countries were included, from } 29 \text { January } 2020 \mathrm{up} \text { to } 15 \text { April } 2021 .\end{array}$} \\
\hline
\end{tabular}

Table 3. Results of the non-linear Poisson mixed model of number of daily COVID-19 deaths with interactions between variants proportions and vaccination efficacy

\begin{tabular}{|c|c|c|c|}
\hline Variable & Estimate & Standard Error & P value \\
\hline Intercept & 0.409 & 0.204 & 0.054 \\
\hline Logarithm of number of daily COVID-19 deaths ${ }^{\#}$ & 0.926 & 0.007 & $<0.001$ \\
\hline Logarithm of (number of COVID-19 deaths 7 days before / 14 days before) & 0.158 & 0.015 & $<0.001$ \\
\hline Proportion of $20 \mathrm{~A}(\mathrm{EU} 2)$ variant* & 0.012 & 0.036 & 0.747 \\
\hline Proportion of $20 \mathrm{E}$ (EU1) variant* & -0.034 & 0.047 & 0.467 \\
\hline Proportion of 20I (B.1.1.7) variant* & 0.059 & 0.033 & 0.085 \\
\hline Max daily temperature* & -0.005 & 0.001 & $<0.001$ \\
\hline Mean daily wind speed* & -0.002 & 0.002 & 0.346 \\
\hline Arrivals at two biggest airports [in thousands]* & 0.703 & 0.085 & $<0.001$ \\
\hline Mobility change from pre-pandemic ${ }^{* 1}$ & 0.753 & 0.064 & $<0.001$ \\
\hline
\end{tabular}


medRxiv preprint doi: https://doi.org/10.1101/2021.05.26.21257844; this version posted May 29, 2021. The copyright holder for this preprint (which was not certified by peer review) is the author/funder, who has granted medRxiv a license to display the preprint in perpetuity.

All rights reserved. No reuse allowed without permission.

\begin{tabular}{|l|r|r|r|}
\hline Variable & \multicolumn{1}{|c|}{ Estimate } & Standard Error & \multicolumn{1}{c|}{ P value } \\
\hline Proportion of inhabitants aged $\geq 65^{\wedge}$ & -0.805 & 0.925 & 0.391 \\
\hline Diabetes prevalence & 0.124 & 1.285 & 0.924 \\
\hline Cardiovascular death rate & 0.025 & 0.023 & 0.278 \\
\hline Vaccination efficacy against 20I (B.1.1.7)* & 0.697 & 0.201 & 0.002 \\
\hline Vaccination efficacy against variants other than 20I (B.1.1.7)* & 0.778 & 0.379 & 0.049 \\
\hline Variance for $R E$ on intercept & 0.013 & 0.006 & 0.025 \\
\hline Variance for $R E$ on mobility & 0.035 & 0.023 & 0.132 \\
\hline
\end{tabular}

$\mathrm{AIC}=30186$.

${ }^{\#}$ Time-varying variable with a 7 -days lag.

* Time-varying variable with a 21 -days lag.

^Fixed variable.

${ }^{1}$ Average mobility change from pre-pandemic calculated across retail/recreation, transit stations and groceries/pharmacies [0.01].

Abbreviations: AIC $=$ Akaike's Information Criterion; $\mathrm{mln}=$ million; $\mathrm{RE}=$ random effects.

Non-linear Poisson mixed model of daily number of COVID-19 deaths per $1 \mathrm{mln}$ inhabitants, with country-specific random effects on intercept and mobility, including interactions between variants proportions and vaccination efficacy. Daily data for 32 countries were included, from 29 January 2020 up to 15 April 2021. 
medRxiv preprint doi: https://doi.org/10.1101/2021.05.26.21257844; this version posted May 29, 2021. The copyright holder for this preprint (which was not certified by peer review) is the author/funder, who has granted medRxiv a license to display the preprint in perpetuity. All rights reserved. No reuse allowed without permission.

\section{Figures}

Figure 1. Cumulative number of COVID-19 deaths per 1 million inhabitants across countries

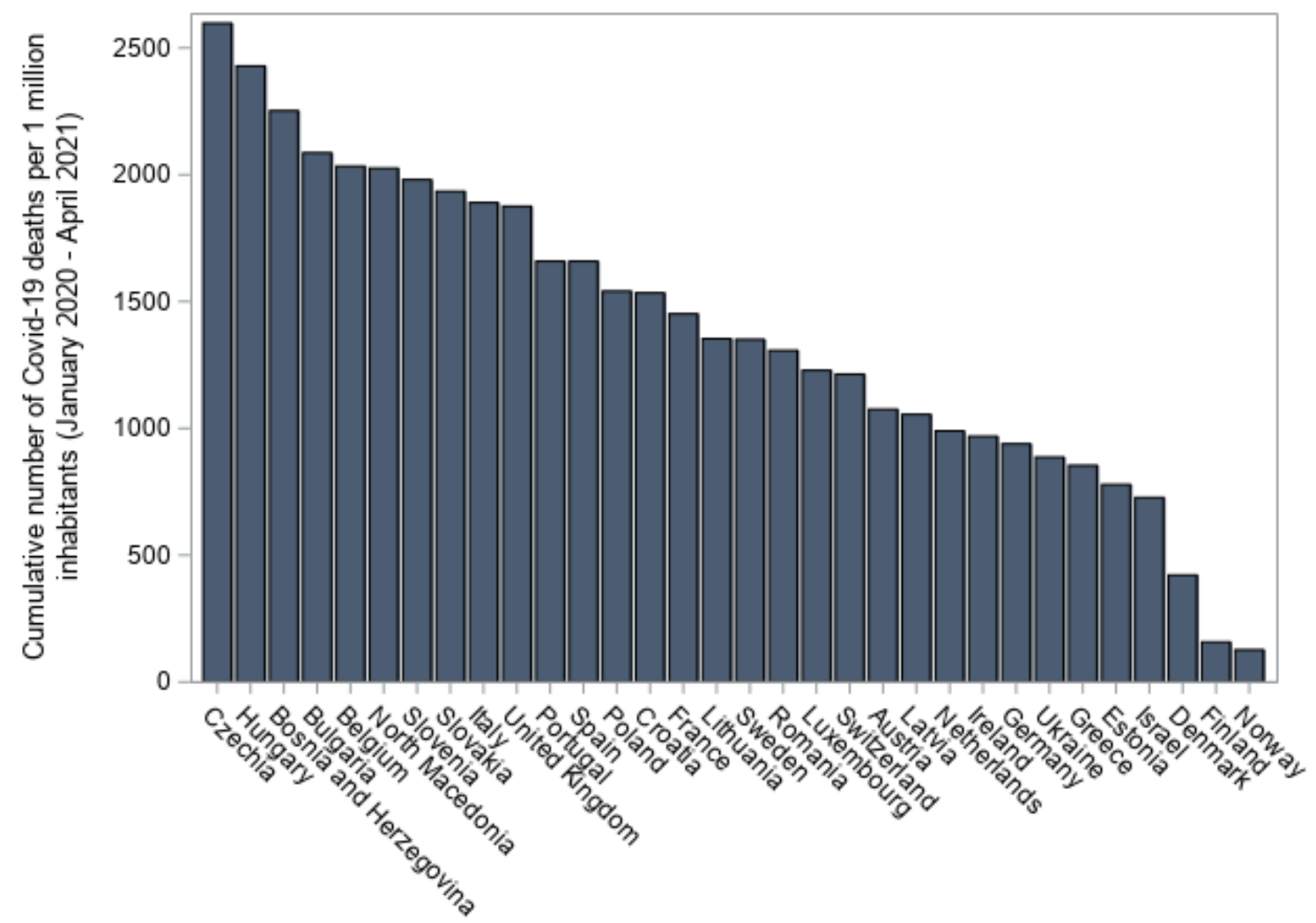

Cumulative number of COVID-19 deaths per one million inhabitants were calculated based on data on mortality between 29 January 2020 and 15 April 2021. 
medRxiv preprint doi: https://doi.org/10.1101/2021.05.26.21257844; this version posted May 29, 2021. The copyright holder for this preprint (which was not certified by peer review) is the author/funder, who has granted medRxiv a license to display the preprint in perpetuity.

All rights reserved. No reuse allowed without permission.

Figure 2. Mean SARS-CoV-2 variants proportions across countries, between January 2020 and April 2021
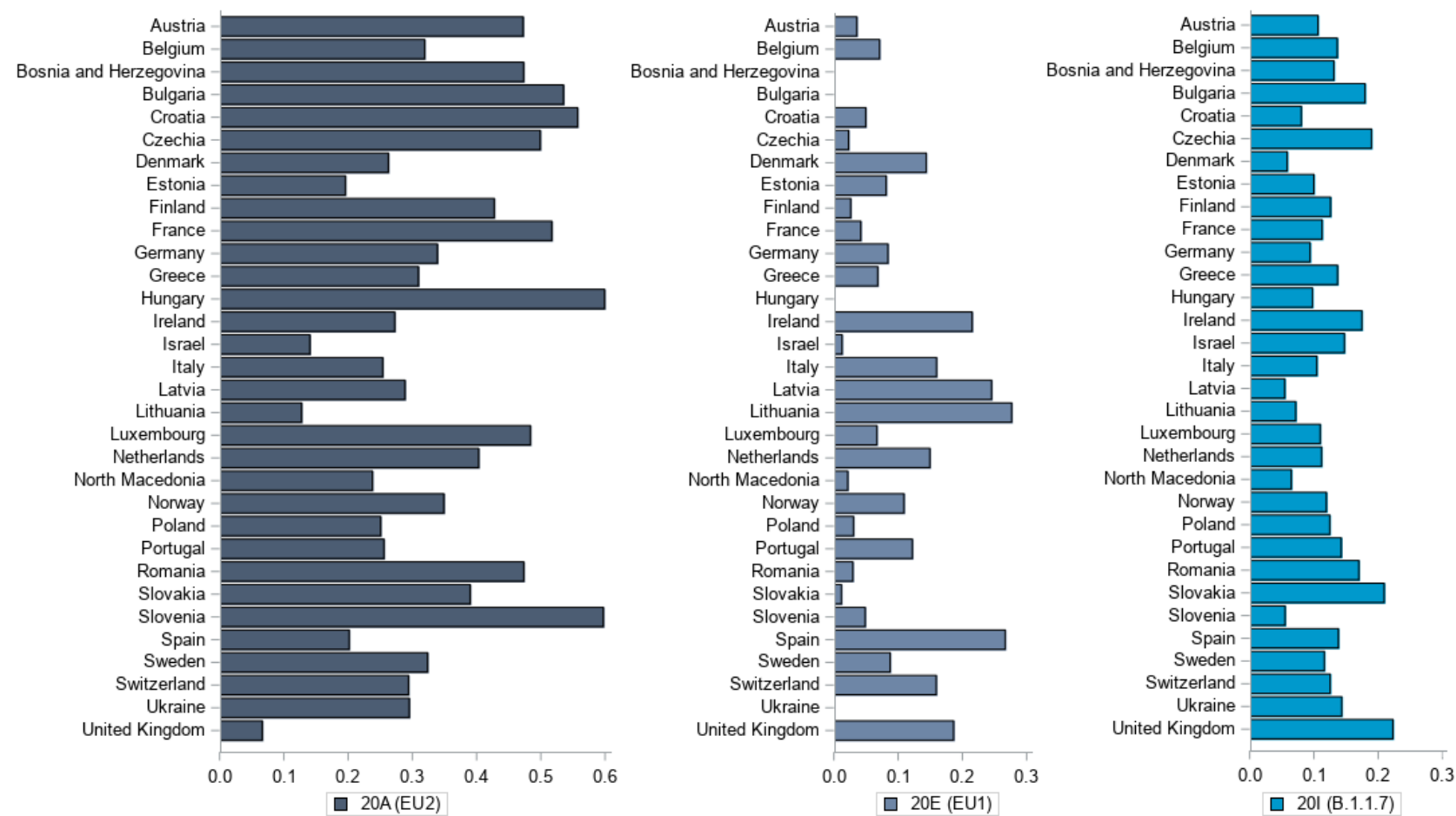

Mean proportions of variants were calculated based on daily data on variants proportions across observed strains used to form Nextstrain clades (variants), between 29 January 2020 and 15 April 2021. 